\title{
Delays in Building Construction Projects in Ghana
}

Frank D.K. Fugar and Adwoa B. Agyakwah-Baah, (Department of Building Technology, Kwame Nkrumah University of Science and Technology, Kumasi, Ghana)

\begin{abstract}
This study investigates the causes of delay of building construction projects in Ghana to determine the most important according to the key project participants; clients, consultants, and contractors. Thirty-two possible causes of delay were identified from the literature and semi-structured interviews of 15 key players in the implementation process. These delay factors were further categorised into nine major groups. The list of delay causes was subjected to a questionnaire survey for the identification of the most important causes of delay. The field survey included 130 respondents made up of 39 contractors, 37 clients and 54 consultants. The relative importance of the individual causes and the groups were calculated and ranked by their relative importance index. The overall results of the study indicate that the respondents generally agree that financial group factors ranked highest among the major factors causing delay in construction projects in Ghana. The financial group factors were delay in honouring payment certificates, difficulty in accessing credit and fluctuation in prices. Materials group factors are second followed by scheduling and controlling factors.
\end{abstract}

Keywords: Building construction projects, Delay causes, Ghana

\section{Introduction}

The literature is replete with studies of construction delays and their negative impact on project success and company performance (Couto and Teixeira, 2007). Many of these studies, according to Couto and Teixeira, had the following objectives:

- To analyse the reasons and factors of project delays

- To classify and evaluate delays, claims and related issues

- To understand, comparing and specifying their issues

Delays are insidious often resulting in time overrun, cost overrun, disputes, litigation, and complete abandonment of projects (Sambasivan and Soon, 2007). Many projects are of such a nature that the client will suffer hardship, expense, or loss of revenue if the work is delayed beyond the time specified in the contract (Clough, 1986). Then again, delay has cost consequences for the contractor: standby costs of non-productive workers, supervisors, and equipment, expenses caused by disrupted construction and material delivery schedules and additional overhead costs (Clough, 1986).

Construction delay is a major problem facing the Ghanaian construction industry. It is endemic and its economic and social impact is often discussed. However, studies on the causes could not be found in the published literature except the study by Frimpong and Oluwoye (2003) which investigated the significant factors that cause delay and cost overruns in the construction of underground projects in Ghana. They reported that to a large extent, 
consultants, owners, and contractors agreed that project financing, economic and natural conditions and material supply were the four major categories of causes of delay and cost overrun factors. This important research leaves a gap which the current study sought to fill, namely to find the causes of delay in building construction projects.

The construction industry is an important sector of the Ghanaian economy. It contributes an average of $8.5 \%$ of the Gross Domestic Product (Ghana Statistical Service, 2007). It employed about $2.3 \%$ of the economically active population in 2002 (Amankwa, 2003). The industry provides means of production for other industries or commodities to be consumed. As Ghana aspires to become a middle income nation by 2015 , and with the recent discovery of oil in commercial quantities, the role of the construction industry is absolutely important. It is against this backdrop that investigating the factors responsible for delays in building construction and recommending measures to eradicate or minimize them assume tremendous importance.

\section{Objective of the Study}

The main objective of this study is to identify the major causes of delays of building construction projects in Ghana using an opinion survey. The primary aim is to identify the perceptions of the three main parties regarding the causes of delays and to suggest possible ways of eradicating or minimising them.

\section{Literature Review}

Sanders and Eagles (2001) define delay as an event that causes extended time to complete all or part of a project. Delay may also be defined as the time overrun, either beyond the date for completion specified by the contract or beyond the extended contract period where an extension of time has been granted. The type of delay we focus on in this study is the time overrun beyond the date for completion specified by the contract not considering whether an extension of time has been granted.

Delay in construction is a global phenomenon (Sambasivan and Soon, 2007) affecting not only the construction industry but the overall economy of countries as well (Faradi and ElSayegh, (2006). Delay involves multiple complex issues all of which are invariably of critical importance to the parties to the construction contract. These issues concern entitlement to recover costs of delay or the necessity to prolong the project with the consequential entitlement to recovery costs for adjustments to the contract schedules. Questions arise as to the causes of delay and the assigning of fault often evolves into disputes and litigation (Bolton, 1990).

Today, many stakeholders in construction are becoming increasingly concerned about the duration of construction projects because of increasing interest rates, inflation, commercial pressures (Nkado, 1995), and of course, it's potential to result in disputes and claims leading to arbitration or litigation.

\section{Classification of Delay}

Delays in construction are caused by several factors. Ahmed et al. (2003) grouped delays into two categories - internal causes and external causes. Internal causes arise from the parties to the contract (e.g. contractor, client, and consultant). External causes, on the other hand, arise from events beyond the control of the parties. These include the act of God, government action, and material suppliers. Bolton (1990) classifies delay as follows: 
- Excusable but non-compensable delay -these are delays caused by occurrences which are not attributable to any of the parties.

- Compensable delay - these delays result from acts or omissions of the owner or someone for whose acts an owner is liable.

- Inexcusable delay - these delays result from a contractor's own fault or his subcontractors or material suppliers.

\section{Related Studies}

A number of studies have been carried out to determine the causes of delay in construction projects. Sweis et al. (2008) studied the causes of delay in residential projects in Jordan and concluded that financial difficulties faced by the contractor and too many change orders by the owner are the leading causes of construction delay. Abd El-Razek et al. (2008) in a similar study in Egypt found that the most important causes of delay are financing by contractor during construction, delays in contractor's payment by owner, design changes by owner or his agent during construction, partial payments during construction, and nonutilization of professional construction/contractual management.

Assaf and AlHejji (2006) conducted a time performance survey of different types of construction projects in Saudi Arabia to determine the causes of delay and their importance according to each project participant (owner, consultant, and contractor). They identified seventy three (73) causes of delay during the research. The most common cause of delay identified by all three parties was "change order."

About a decade earlier, Assaf et al. (1995) studied the causes of delay in large building projects in Saudi Arabia and their relative importance and reported that among the fifty-six (56) causes of delay included in the survey, the contractors, owners and architects/engineers interviewed all ranked financing group delay factors the highest. According to the contractors, the most important delay factors were preparation and approval of shop drawings, delays in contractors' progress payment by owners, and design changes by owners. In the opinion of architects and engineers, the most important causes of delay were cash flow problems during construction, the relationship between different subcontractors' schedules in the execution of the project, and the slowness of the owners' decision-making process. Owners, on the other hand, attributed delays in construction projects to design errors, excessive bureaucracy in project-owner organization, labour shortages, and inadequate labour skills. Furthermore, Assaf et al, in a review of the literature, reported that studies by Chalabi and Camp (1984) had established that in developing countries where workers are relatively unskilled, adequate planning at the very early stages of the project was important for minimizing delay and cost overruns in most projects. It is however, interesting to note that financial difficulty as a factor in the delay of projects in Saudi Arabia was not reported as a major factor again in the Assaf et al. (2006) study.

Ayman (2000) investigated the causes of delays on 130 public projects in Jordan. The projects included residential, office and administration buildings, school buildings, medical centres, and communication facilities. The results indicated that the main causes of delay in construction of public projects relate to designers, user changes, weather, site conditions, late deliveries, economic conditions, and increase in quantity. Odeh and Battaineth (2001) reported that among the top ten most important causes of delays in construction projects with traditional type contracts in Jordan were, from the view point of contractors and consultants: owner interference, inadequate contractor experience, financing and payments, labour productivity, slow decision making, improper planning, and subcontractors. 
Sambasvian and Soon (2007) identified the delay factors and their impact on project completion in the Malaysian construction industry. The results indicated that the ten from a list of 28 different causes of delay were: (1) contractor's improper planning, (2) contractor's poor site management, (3) inadequate contractor experience, (4) client's inadequate financial resources and payments for completed work, (5) problems with subcontractors, (6) shortage in material, (7) labour supply, (8) equipment availability and failure, (9) lack of communication between parties, and (10) mistakes during the construction stage.

A similar study in Malaysia by Alaghbari et al. (2007) indicated that from a list of thirty-one (31) factors, clients, contractors and consultants agreed that financial problems were the main factors and coordination problems were the second most important factor causing delay in construction projects in Malaysia.

This review has underscored that the factors that cause delay in construction projects are many and vary from country to country and from one circumstance to another. However, in developing economies Ogunlana et al. (1996) have reported that there are distinctive problems that cause delays in construction. They have classified them into three groups: (a) problems of shortage or inadequacies in industry infrastructure (mainly supply of resources), (b) problems caused by clients and consultants, and (c) problems caused by contractor incompetence/inadequacies.

\section{Data Collection}

The data collection process involved two stages. The first stage consisted of literature search for information on the causes of delay in other countries and non-structured interviews of 15 key players involved in the implementation process selected by a non-probabilistic snow ball technique. The purpose of interviewing the key players was essentially to validate a preliminary set of construction delay causes gleaned from the literature and to determine from their experience other factors which cause construction delay in Ghana. To ensure a balanced view, the interviewees consisted of 5 each of contractors, client's representatives and consultants.

\begin{tabular}{|l|c|c|c|}
\hline \multicolumn{1}{|c|}{ Respondents } & $\begin{array}{c}\text { Questionnaire } \\
\text { distributed }\end{array}$ & $\begin{array}{c}\text { Responses } \\
\text { returned }\end{array}$ & $\begin{array}{c}\text { Percentage of } \\
\text { responses }\end{array}$ \\
\hline Client & 55 & 37 & $67 \%$ \\
\hline Contractors & 55 & 39 & $71 \%$ \\
\hline Consultants & 55 & 54 & $98 \%$ \\
\hline Total & 165 & 130 & $79 \%$ \\
\hline
\end{tabular}

Table 1 Percentage of questionnaire distributed and responses received

This phase resulted in the identification of thirty-two (32) causes of delay. The second stage involved the development of questionnaire incorporating the 32 causes of delay identified and data collection. The questionnaire was organised in the form of an importance scale. Respondents, were asked to indicate by ticking a column the relative importance of each of the causes of construction delay (in terms of $4=$ 'very important', 3 = 'important', $2=$ 'somewhat important', 1 = 'not important'). A total of 165 questionnaires were distributed to respondents in the Greater Accra Region of Ghana where the concentration of contractors and consultants is highest. Fifty-five (55) questionnaires were dispensed to each category of the respondents - clients, consultants and contractors. The convenience or availability sampling approach was used in the selection of respondents. Gabor (1993) and Baley (1994) describe this type of sampling as one where the researcher uses cases that are most 
convenient and available. It is made up of whoever is willing to participate. The disadvantage of this approach is its tremendous potential for bias (Frey et al., 1991). However, considering that this is a preliminary study, convenience sampling was considered appropriate. The questionnaires were personally delivered to the respondents by the researchers who also went back to collect them at appointed times. The collection of data took 4 weeks. At end of the period, 130 questionnaires (79\%) were received for analysis out of which 54 were responses from consultants. This response rate by consultants is extremely high, higher than expected in any research. This group of respondents were most enthusiastic and cooperative.

\section{Data Analysis}

The survey data consisting of the 32 causes of delay were analysed and grouped into nine major areas according to a slightly modified version of Assaf et al.'s (1995) classifications: materials, manpower, equipment, financing, environment, changes, government action, contractual relationships, and scheduling and controlling techniques. Assaf et al.'s seventh major classification was 'Government relations' which these researchers substituted with 'Government action.' It was felt that the relevant causes of delay grouped under this heading could more appropriately be described as actions of government.

1. Material

- shortages of materials on site or market

- Late delivery of material

\section{Manpower}

- shortage of unskilled labour

- shortage of skilled labour

\section{Equipment}

- equipment failure or breakdown

- unskilled equipment operators

\section{Financing}

- Delay in honouring payment certificates

- Difficulties in assessing credit

- Fluctuation of prices

5. Environmental

- Bad weather conditions

- Unfavourable site conditions

6. Changes

- client initiated variations

- necessary variations

- mistakes in soil investigation

- poor design

- foundation conditions encountered on site

\section{Government action}

- delays in obtaining permit from municipality

- public holidays

- discrepancy between design specification and building code

8. Contractual relations

- legal disputes

- insufficient communication between parties

- poor professional management

- delay in instructions from consultants

- delay by subcontractors

\section{Scheduling and controlling} techniques

- poor site management

- poor supervision

- lack of programme of works

- accidents during construction

- construction methods

- underestimation of costs of projects

- underestimation of complexity of projects

- underestimation of time of completion 


\section{Relative importance index (RII)}

\begin{tabular}{|c|c|c|c|c|c|c|c|}
\hline \multirow[t]{2}{*}{ Factors } & \multicolumn{2}{|c|}{ Clients } & \multicolumn{2}{|c|}{ Contractor } & \multicolumn{2}{|c|}{ Consultant } & \multirow{2}{*}{$\begin{array}{l}\text { Overal } \\
\text { Rank }\end{array}$} \\
\hline & RII & Rank & RII & Rank & RII & Rank & \\
\hline Delay in honouring payment certificates & 0.831 & 1 & 0.932 & 1 & 0.852 & 1 & 1 \\
\hline Underestimation of cost of projects & 0.824 & 2 & 0.845 & 5 & 0.792 & 3 & 2 \\
\hline Underestimation of complexity of projects & 0.784 & 6 & 0.824 & 8 & 0.792 & 3 & 3 \\
\hline Difficulty in accessing Bank credit & 0.797 & 4 & 0.858 & 2 & 0.755 & 9 & 4 \\
\hline Poor supervision & 0.743 & 10 & 0.858 & 2 & 0.773 & 5 & 4 \\
\hline $\begin{array}{l}\text { Underestimation of time for completion by } \\
\text { contractors }\end{array}$ & 0.757 & 8 & 0.764 & 12 & 0.801 & 2 & 6 \\
\hline Shortage of materials & 0.696 & 17 & 0.851 & 4 & 0.759 & 8 & 7 \\
\hline Poor Professional Management & 0.804 & 3 & 0.73 & 17 & 0.764 & 7 & 8 \\
\hline Fluctuation of prices & 0.757 & 8 & 0.811 & 9 & 0.736 & 11 & 8 \\
\hline Poor Site management & 0.797 & 4 & 0.743 & 15 & 0.750 & 10 & 10 \\
\hline Construction methods & 0.743 & 10 & 0.791 & 10 & 0.736 & 11 & 10 \\
\hline Delay in instructions from consultants & 0.709 & 16 & 0.831 & 7 & 0.708 & 17 & 12 \\
\hline Late deliveries of materials & 0.655 & 25 & 0.838 & 6 & 0.731 & 13 & 12 \\
\hline Lack of Programme of Works & 0.730 & 12 & 0.709 & 20 & 0.769 & 6 & 14 \\
\hline Delay by sub-contractors & 0.696 & 17 & 0.791 & 10 & 0.731 & 13 & 14 \\
\hline Poor design & 0.730 & 12 & 0.757 & 14 & 0.727 & 15 & 16 \\
\hline Breakdown of equipments & 0.764 & 7 & 0.743 & 15 & 0.704 & 20 & 17 \\
\hline Client initiated variations & 0.716 & 14 & 0.764 & 12 & 0.708 & 17 & 17 \\
\hline Obtaining permit from municipality & 0.689 & 21 & 0.723 & 19 & 0.676 & 22 & 17 \\
\hline Insufficient communication between parties & 0.662 & 23 & 0.730 & 17 & 0.681 & 21 & 17 \\
\hline Necessary variations & 0.696 & 17 & 0.689 & 22 & 0.667 & 23 & 21 \\
\hline Shortage of skilled labour & 0.689 & 17 & 0.581 & 28 & 0.718 & 16 & 21 \\
\hline Legal disputes & 0.716 & 14 & 0.628 & 26 & 0.653 & 25 & 23 \\
\hline Unfavourable Site conditions & 0.696 & 17 & 0.669 & 23 & 0.639 & 27 & 23 \\
\hline Foundation conditions encountered on site & 0.655 & 25 & 0.608 & 27 & 0.708 & 17 & 25 \\
\hline $\begin{array}{l}\text { Discrepancy between design specification } \\
\text { and building code }\end{array}$ & 0.642 & 27 & 0.649 & 24 & 0.662 & 24 & 25 \\
\hline Bad weather conditions & 0.635 & 28 & 0.709 & 20 & 0.597 & 28 & 27 \\
\hline Mistakes with soil investigations & 0.662 & 23 & 0.579 & 29 & 0.648 & 26 & 28 \\
\hline Unskilled equipment operators & 0.601 & 29 & 0.635 & 25 & 0.588 & 29 & 29 \\
\hline Accidents during construction & 0.554 & 30 & 0.486 & 30 & 0.565 & 30 & 30 \\
\hline Shortage of unskilled labour & 0.473 & 31 & 0.446 & 31 & 0.468 & 31 & 31 \\
\hline Public holidays & 0.432 & 32 & 0.412 & 32 & 0.403 & 32 & 32 \\
\hline
\end{tabular}

Table 2 Relative Importance Index and Rank of Delay Factors according to Clients, Contractors and Consultants 


\begin{tabular}{|c|c|c|c|c|c|c|c|c|}
\hline \multirow{2}{*}{ GROUPS } & \multicolumn{8}{|c|}{ IMPORTANCE INDECES } \\
\hline & CONT. & RANK & CLIENT & RANK & CONS. & RANK & ALL & RANK \\
\hline FINANCING & 0.867 & 1 & 0.795 & 1 & 0.781 & 1 & 2.802 & 1 \\
\hline Delay in honouring payment certificates & 0.932 & & 0.831 & & 0.852 & & 3.007 & \\
\hline Difficulty in accessing Bank credit & 0.858 & & 0.797 & & 0.755 & & 2.757 & \\
\hline Fluctuation of prices & 0.811 & & 0.757 & & 0.736 & & 2.642 & \\
\hline MATERIALS & 0.845 & 2 & 0.676 & 6 & 0.745 & 3 & 2.608 & 2 \\
\hline Shortage of materials & 0.851 & & 0.696 & & 0.759 & & 2.655 & \\
\hline Late deliveries of materials & 0.838 & & 0.655 & & 0.731 & & 2.561 & \\
\hline SCHEDULING AND CONTROLLING & 0.753 & 3 & 0.742 & 2 & 0.747 & 2 & 2.585 & 3 \\
\hline Poor supervision & 0.858 & & 0.743 & & 0.773 & & 2.730 & \\
\hline Accidents during construction & 0.486 & & 0.554 & & 0.565 & & 1.865 & \\
\hline Poor site management & 0.743 & & 0.797 & & 0.750 & & 2.635 & \\
\hline Lack of programme of works & 0.709 & & 0.730 & & 0.769 & & 2.561 & \\
\hline Construction methods & 0.791 & & 0.743 & & 0.736 & & 2.608 & \\
\hline Underestimation of costs of projects & 0.845 & & 0.824 & & 0.792 & & 2.824 & \\
\hline Underestimation of complexity of projects & 0.824 & & 0.784 & & 0.792 & & 2.764 & \\
\hline Underestimation of time of completion & 0.764 & & 0.757 & & 0.801 & & 2.689 & \\
\hline CONTRACTUAL RELATIONSHIP & 0.742 & 4 & 0.718 & 3 & 0.707 & 4 & 2.492 & 4 \\
\hline Poor professional management & 0.730 & & 0.804 & & 0.764 & & 2.649 & \\
\hline Legal disputes & 0.628 & & 0.716 & & 0.653 & & 2.297 & \\
\hline Insufficient communication between parties & 0.730 & & 0.662 & & 0.681 & & 2.385 & \\
\hline Delay in instructions from consultants & 0.831 & & 0.709 & & 0.708 & & 2.574 & \\
\hline Delay by subcontractors & 0.791 & & 0.696 & & 0.731 & & 2.554 & \\
\hline CHANGES & 0.678 & 7 & 0.701 & 4 & 0.692 & 5 & 2.380 & 5 \\
\hline Client initiated variations & 0.764 & & 0.761 & & 0.708 & & 2.514 & \\
\hline Necessary variations & 0.689 & & 0.696 & & 0.667 & & 2.358 & \\
\hline Mistakes with soil investigations & 0.574 & & 0.662 & & 0.648 & & 2.182 & \\
\hline Foundation conditions encountered on site & 0.608 & & 0.655 & & 0.708 & & 2.297 & \\
\hline Poor Design & 0.757 & & 0.730 & & 0.727 & & 2.547 & \\
\hline EQUIPMENT & 0.690 & 5 & 0.683 & 5 & 0.646 & 6 & 2.315 & 6 \\
\hline Unskilled equipment operators & 0.635 & & 0.601 & & 0.588 & & 2.095 & \\
\hline Breakdown of equipments & 0.745 & & 0.764 & & 0.704 & & 2.534 & \\
\hline ENVIRONMENT & 0.689 & 6 & 0.666 & 7 & 0.618 & 7 & 2.257 & 7 \\
\hline Bad weather conditions & 0.709 & & 0.635 & & 0.597 & & 2.216 & \\
\hline Unfavourable site conditions & 0.669 & & 0.696 & & 0.639 & & 2.297 & \\
\hline GOVERNMENT ACTION & 0.595 & 8 & 0.588 & 8 & 0.580 & 9 & 2.029 & 8 \\
\hline Obtaining permit from municipality & 0.723 & & 0.689 & & 0.676 & & 2.399 & \\
\hline $\begin{array}{l}\text { Discrepancy between design specification } \\
\text { and building code }\end{array}$ & 0.649 & & 0.642 & & 0.662 & & 2.257 & \\
\hline Public holidays & 0.412 & & 0.432 & & 0.403 & & 1.432 & \\
\hline MANPOWER & 0.514 & 9 & 0.581 & 9 & 0.593 & 8 & 1.960 & 9 \\
\hline Shortage of skilled labour & 0.581 & & 0.689 & & 0.718 & & 2.318 & \\
\hline Shortage of unskilled labour & 0.446 & & 0.473 & & 0.468 & & 1.601 & \\
\hline
\end{tabular}

Table 3 Index and Rank of Causes of Groups of Delay Factors

Fugar, F D K and Agyakwah-Baah, A B (2010) 'Delays in building construction projects in Ghana', Australasian Journal of Construction Economics and Building, 10 (1/2) 103-116 
The aim of the analysis was to establish the relative importance of the various factors identified as responsible for construction delay. The score for each factor is calculated by summing up the scores given to it by the respondents. The relative importance index (RII) was calculated using the following formula (Fagbenle et al., 2004):

$$
\begin{aligned}
& \qquad \mathrm{RII}=\sum_{\mathrm{N}} \mathrm{P}_{\mathrm{i}} \mathrm{U}_{\mathrm{i}} \ldots \ldots \ldots \ldots \ldots \ldots \ldots \ldots \ldots \ldots \ldots \ldots \\
& \text { Where, } \\
& \mathrm{RII}=\text { relative importance index } \\
& \mathrm{P}_{\mathrm{i}}=\text { respondent's rating of cause of delay } \\
& \mathrm{U}_{\mathrm{i}}=\text { number of respondents placing identical weighting/rating on cause of delay } \\
& \mathrm{N}=\text { sample size } \\
& \mathrm{n}=\text { the highest attainable score on cause of delay }
\end{aligned}
$$

The relative importance index for all the delay factors and groups was calculated using the equation (1) above. The indexes were ranked for clients, contractors and consultants. The group index is the average of relative importance index of the delay factors in each group.

\section{Agreement analysis}

The Spearman's rank correlation coefficient $(\rho)$ was used to show the degree of agreement between the rankings of any two parties. The Spearman's rank correlation is a nonparametric test. Non-parametric tests are also referred to as distribution-free tests. These tests do not require the assumption of normality or the assumption of homogeneity of variance. They compare medians rather than means and, as a result, if the data include one or two outliers, their influence is excluded. The Spearman's rank correlation coefficient $(\rho)$ was calculated as follows:

$$
\underset{n\left(n^{2}-1\right) \ldots \ldots \ldots .}{\rho=1-6 \sum d^{2}}
$$

Where:

$d=$ the difference between the ranks given by any two respondents for an individual cause and

$\mathrm{n}=$ the number of causes or groups, which in this case is 32 causes or 9 groups.

The rank correlation coefficients for the delay factors are $0.69,0.82$, and 0.70 for clients and contractors, clients and consultants and contractors and consultants respectively. This shows high agreement between rankings.

\section{Significance test}

To determine whether the parties displayed significant agreement in their rankings, the null hypothesis that "clients and contractors, clients and consultants, and contractors and consultants do not agree on ranking of important delay factors" was tested using a t-test at a $95 \%$ confidence level. The null hypothesis was rejected in all three cases. The alternate hypothesis that all three parties generally agreed on the ranks was accepted.

The rank correlation coefficients calculated for the nine groups of delay factors were 0.76 , 0.88 and 0.92 for clients and contractors, clients and consultants and contractors and consultants respectively. Again utilising a $t$-test at a $95 \%$ confidence level of the same null hypothesis for the group delay factors resulted in the rejection of the null hypothesis in all three cases. Therefore, all the three parties generally agree on the ranking of the group factors of delays. 


\section{Results and Discussion}

The perspectives of clients, consultants and contractors of the 32 delay factors were analysed based on the relative importance index. The results are shown in Tables 2 and 3 above. The relative importance index and ranks of delay factors by all the respondents are presented in Table 2. Table 3 illustrates the relative importance index and ranks of groups of delay factors by all respondents.

Generally, all major stake holders agreed that the top ten most important factors causing delay in Ghana are:

- delay in honouring certificates

- underestimation of the cost of project

- underestimation of complexity of project

- difficulty in accessing bank credit

- poor supervision

- underestimation of time for completion of projects by contractors

- shortage of materials

- poor professional management

- fluctuation of prices/rising cost of materials

- poor site management

.

Based on the different groups of delay, the respondents generally agreed that the top three groups of delay are:

- financial

- materials

- scheduling and control.

The following brief discussion is focused on the nine groups of delays in descending order of their ranking.

\section{Financial}

The financial group of delay was ranked highest by all the respondents put together. This result agrees with Frimpong and Oluwoye (2003) who found that financial problems are the main factors that cause delay in the construction of groundwater projects in Ghana. Financial difficulties have also been identified as the first major factor causing delay in construction projects in Malaysia (Alaghbari et al. 2007, Assaf et al. 1995). The inability of clients (building owners) to honour payments on time was determined by all respondents under the financial group of delays as the first major factor that causes delays in building construction projects in Ghana. It is encouraging to note that clients interviewed also admitted that their inability to provide the needed funds on time is the most important delay factor. In Ghana, the long and bureaucratic processes involved in honouring payments to contractors, especially those working on government projects have been well documented. Failure to pay contractors regularly for work done impedes progress and causes delay. And failure to provide adequate funding resources to contractors will make it impossible for contractors to meet project of objectives (Oglesby, Parker, Howell, 1989).

\section{Material shortage}

The material group delay factors were ranked the second most important factors responsible for construction delay. This is not surprising because barring the shortage of material on the market, the availability of materials on site at the right time and in the right quantities is

Fugar, F D K and Agyakwah-Baah, A B (2010) 'Delays in building construction projects in Ghana', Australasian Journal of Construction Economics and Building, 10 (1/2) 103-116 
directly related to the ability of the client to honour certificates as and when they are due. Liquidity problems make it difficult for contractors to procure materials. Again, materials suppliers are reluctant to supply materials on credit because contractors will normally pay suppliers only when they themselves are paid.

\section{Scheduling and controlling}

Contractors, clients, and consultants together ranked scheduling and controlling of work as the third most crucial factor in the delay of building construction projects with the relative importance index of $0.753,0.742$, and 0.747 respectively. Within this group, contractors ranked occurrence of accidents on site the most important factor in the delay of construction projects. Clients on the other hand ranked underestimation of construction costs by contractors the most important. Yet still, consultants ranked underestimation of time of completion by contractors as the most important delay factor. Put together, this may be due to the lack of personnel with management and estimating skills within the contractors' organization. There is abundant anecdotal evidence to support the assertion that many local contractors are reluctant to employ high level skilled staff, such as University graduates. Indeed, many contractors in developing countries are entrepreneurs who are in the business to make more profit (Ogulana and Olomolaiye ,1989; Wahab, 1997) and therefore, may not be willing to pay highly skilled staff.

\section{Contractual relationship}

Contractual relationship as a delay group was ranked fourth. Within this group, clients and consultants agreed that poor professional management was the most important factor in the delay of building projects. On the other hand, contractors ranked delay in the receipt of instructions from consultants the most important factor. The purpose of conditions of contract which are incorporated in construction contracts is to amplify and explain the basic obligations of parties to the contract. The conditions also provide the administrative mechanisms for ensuring that the correct procedures are observed (Murdoch and Hughes, 1992). Unfortunately, there is the perception that some parties are not very familiar with the conditions of contract resulting in breaches causing delay.

\section{Changes}

This delay group factor was ranked fifth. Contractors and clients agreed that within this group, client initiated variations is the most important delay factor in causing construction delay. However, consultants ranked poor design highest.

\section{Equipment}

The equipment group of delays factor was ranked sixth. It is not surprising that equipment group factors were ranked among the least important. Construction is Ghana is labour intensive with basic hand tools and equipment. The extensive use of major equipment is rare on many projects. Where equipment is required, the contractors have the option to hire. In the rare cases where some plant and equipment are owned by a contractor, breakdown is a major delay factor perhaps owing to old age or lack of planned maintenance.

\section{Environment}

Clients and consultants both agreed that within the environment group of delay factors, an unfavourable site condition was a major delay factor. On the other hand, contractors ranked bad weather conditions as the most important factor. Relatively, environmental conditions as a delay factor is ranked low. Bad weather conditions are natural events which cannot be controlled by the parties. In Ghana, the effect of inclement weather on progress may not be significant but needs to be taken into account. The climate is tropical with wet and dry

Fugar, F D K and Agyakwah-Baah, A B (2010) 'Delays in building construction projects in Ghana', Australasian Journal of Construction Economics and Building, 10 (1/2) 103-116 
seasons. During the rainy season construction work may be disrupted especially outdoor activities. During the rainy season temperatures range from $21^{\circ} \mathrm{C}$ to $32^{\circ} \mathrm{C}$ and the humidity is relatively high. The rest of the year is hot and dry with temperatures reaching $38^{\circ} \mathrm{C}$. The high temperatures and high humidity ranging from 25 to $80 \%$ certainly affect the productivity of construction workers as a result of dullness of their senses, poor coordination and discomfort from body heat (Frimpong, Oluwoye, and Crawford, 2003).

\section{Government action}

Government action as a delay group was ranked relatively low. All parties agreed that obtaining approval from the municipality was the most important factor in this category causing construction delay.

\section{Manpower}

All parties ranked the manpower group factor the lowest. Regarding all the factors in the group, all three parties ranked shortage of skilled labour high. As indicated by the respondents, shortage of labour is not a problem in Ghana currently, but there is anecdotal evidence that skilled labour in construction trades is becoming rarer. This challenge requires construction companies and other stakeholders to take steps to entice and train youth in carpentry, masonry, and other trades.

\section{Summary and Conclusion}

This study focused on delay of construction of building projects in Ghana. The study sought the views of clients, consultants, and contractors on the relative importance of the factors that cause delays in building construction projects in Ghana. The study showed that all the three groups of respondents generally agreed that out of a total of 32 factors the top ten influencing factors in causing delay arranged in descending order of importance are:

- delay in honouring certificates

- underestimation of the costs of projects

- underestimation of the complexity of projects

- difficulty in accessing bank credit

- poor supervision

- underestimation of time for completion of projects by contractors

- shortage of materials

- poor professional management

- fluctuation of prices/rising cost of materials

- poor site management.

The 32 factors were categorised into nine major groups and were ranked. The results show that clients, consultants, and contractors all agreed that the financing group of delay factors was the most influential factor. Material factors were considered the second most important factor causing delay in construction projects followed by scheduling and controlling factors.

\section{Recommended Remedies for Delay}

The importance of adequate and timely provision of financial resources in building construction project management cannot be over emphasised. Adequate finance is the hub around which everything else revolves. Everybody and everything connected with construction is adversely affected by lack of sufficient cash flow. The project is not only delayed but the morale of workers plummet because of non-payment or irregular payment of 
wages. Subcontractors and suppliers of materials and components and their employees are likewise affected.

The challenge to construction managers and of course, clients, is to identify ways to eliminate or at least reduce the occurrence of financial crisis during the construction process. In that regard, the following recommendations are made.

- Construction clients must ensure that funds are available or adequate arrangements for funds are made before projects are started.

- The long and bureaucratic processes involved in honouring payments to contractors in Ghana must be shortened for efficiency and contractors' payments must be honoured as and when they due in strict compliance with the provisions of the contract.

- Contract provisions which allow contractors to claim interest on delayed payments must be strictly enforced to serve as deterrent to clients.

- The idea of establishing a commercial bank for building and construction is worth revisiting so that contractors can have access to credit in times of liquidity difficulties.

Again, to overcome some contractors' ineptitude which correlates directly with delay factors such as underestimation of cost, time of completion and complexity of projects, poor scheduling and control and poor site management, the researchers recommend the following actions.

- The Civil Engineering and Building Contractors Association of Ghana must institute measures to ensure that its members go through continual education so that the technical and managerial competences of contractors who belong to it can be improved. The acquisition of a certain number of credit hours in continual education should be a criterion for membership renewal.

- The Ministry of Works and Water Resources, the body responsible for the registration and classification of contractors wishing to execute public projects, must insist on its requirement that contractors must have in their employment certain key technical staff as a condition for registration. Above all, effective ways must be designed to verify the list of staff produced by contractors in support of their application and to ensure also that these key staff positions are continually filled by technically competent individuals.

\section{References}

Abd El-Razek, M.E., Bassioni, H.A.and Mobarak, A.M. (2008) 'Causes of delays in building construction projects in Egypt', Journal of Construction Engineering and Management, 134 (11) 831-841

Ahmed, S.M., Azhar, S., Kappagntula, P., Gollapudil, D. (2003) 'Delays in construction: a brief study of Florida construction industry', Proceedings of the $39^{\text {th }}$ Annual ASC Conference, Clemson University, Clemson, SC, 257-66

Alaghbari, W., Kadir, M.R.A., Salim, A., and Ernawati (2007) 'The significant factors causing delay of building construction projects in Malaysia', Engineering, Construction and Architectural Management, 14 (2), 192-206

Amankwa, O.P.J. (2003) Ghana: A human geography for secondary schools, St. Francis Press, Ghana

Assaf, S.A. AlHejji S. (2006) 'Causes of delay in large construction projects', International Journal of Project Management, 24 (4), 349-357 
Assaf, S.A., Alkhail, M., and Al-Hazmi M. (1995) 'Causes of delay in large building construction projects', Journal of Management in Engineering, ASCE, 11 (2), 45-40

Ayman, H. (Al-Momani) (2000) 'Construction delay: a quantitative analysis', International Journal of Project Management, 18 (1), 51-59

Bailey, K.D. (1994) Methods of social research, $4^{\text {th }}$ ed, Free Press, New York

Bolton, J. (1990) 'Type of claims', Construction and disruption claims, Course Manual, Portman Inter-Continental, London

Chalabi, F.A., and Camp, D. (1984) 'Causes of delays and overruns of construction projects in developing countries', CIB Proc., W-65, Vol. 2, 723-734

Clough, R.H. (1986) Construction contracting, John Wiley and Sons, New York

Fagbenle, O.I., Adeyemi, A.Y., and Adesanya, D.A. (2004) 'The impact of non-financial incentives on briclayers' productivity in Nigeria', Construction Management and Economics, 22, 899-911

Faradi, A.S. and El-Sayegh, S.M. (2006) 'Significant factors causing delay in the UAE construction industry', Construction Management and Economics, 24 (11), 1167-1176

Frey, L.R., Botan, C.H., Friedman, P.G., and Kreps, G.L. (1991) Investigating Communication: An introduction to Research Methods, Prentice Hall, Engle Woods Cliffs

Frimpong, Y., Oluwoye, J., Crawford, L (2003) 'Causes of delay and cost overruns in construction of ground water projects in developing countries: Ghana as a case study', International Journal of Project Management, 21, 321-326

Frimpong, Y. and Oluwoye, J. (2003) 'Significant factors causing delay and cost overruns in construction of groundwater projects in Ghana', Journal of Construction Research, 1 (2), 17587

Gabor, P. (1993) 'Sampling'. in R.M Grinnell, (ed), Social work research and evaluation, $4^{\text {th }}$ ed, Peacock, Itasca, III, 154-170

Murdoch, J. and Hughes, W. (1992) Construction Contracts: Law and Management, E \& FN SPON, London

Nkado, R.N. (1995) Construction Time- Influencing Factors: the Contractors' Perspective, viewed 18 Dec 2006, http://www.misronet.com/articles.htm

Odeh, A.M. and Battaineh H (2002) 'Causes of construction delay: traditional contracts', International Journal of project Management, 20 (1), 67-73

Oglesby, C, Parker, H and Howel, G (1989) Productivity Improvement in Construction, McGraw-Hill, New York

Ogunlana, SO, Olomolaiye, PO (1989) 'A survey of site management practice on some selected sites in Nigeria', Building Environ 24 (2), 191-6

Ogunlana, S.O., Promkuntong, K., and Jearkjirm, V. (1996) 'Construction delays in a fastgrowing economy: comparing Thailand with other economies', International Journal of Project Management, 14 (1), 37-45

Sambasivan, M. and Soon, Y.W. (2007) 'Causes and effects of delays in Malaysian construction industry', International Journal of Project Management, 25 (5), 517-526

Sweis, G., Sweis, R., Abu Hammad, A. and Shboul, A. (2008) 'Delays in construction projects: The case of Jordan', International Journal of Project Management 26 (6) 665-74 Wahab KA (1997) 'Improving efficiency in the building sector', West Africa Tech Rev, 81-9 


\section{Appendix}

Please indicate by ticking the appropriate column the relative importance of each of the following causes of building construction delay

\begin{tabular}{|c|c|c|c|c|c|}
\hline No & Factor of Delay & $\begin{array}{c}\text { Very } \\
\text { Important }\end{array}$ & Important & $\begin{array}{l}\text { Somewhat } \\
\text { important }\end{array}$ & $\begin{array}{c}\text { Not } \\
\text { important }\end{array}$ \\
\hline 1 & Delay in honouring payment certificates & & & & \\
\hline 2 & Underestimation of cost of projects & & & & \\
\hline 3 & Underestimation of complexity of projects & & & & \\
\hline 4 & Difficulty in accessing bank credit & & & & \\
\hline 5 & Poor supervision & & & & \\
\hline 6 & $\begin{array}{l}\text { Underestimation of time for completion } \\
\text { by contractors }\end{array}$ & & & & \\
\hline 7 & Shortage of materials & & & & \\
\hline 8 & Poor professional management & & & & \\
\hline 9 & Fluctuation of prices & & & & \\
\hline 10 & Poor site management & & & & \\
\hline 11 & Construction methods & & & & \\
\hline 12 & Delay in instructions from consultants & & & & \\
\hline 13 & Late deliveries of materials & & & & \\
\hline 14 & Lack of programme of works & & & & \\
\hline 15 & Delay by sub-contractors & & & & \\
\hline 16 & Poor design & & & & \\
\hline 17 & Breakdown of equipments & & & & \\
\hline 18 & Client initiated variations & & & & \\
\hline 19 & Obtaining permit from municipality & & & & \\
\hline 20 & $\begin{array}{l}\text { Insufficient communication between } \\
\text { parties }\end{array}$ & & & & \\
\hline 21 & Necessary variations & & & & \\
\hline 22 & Shortage of skilled labour & & & & \\
\hline 23 & Legal disputes & & & & \\
\hline 24 & Unfavourable site conditions & & & & \\
\hline 25 & $\begin{array}{l}\text { Foundation conditions encountered on } \\
\text { site }\end{array}$ & & & & \\
\hline 26 & $\begin{array}{l}\text { Discrepancy between design } \\
\text { specification and building code }\end{array}$ & & & & \\
\hline 27 & Bad weather conditions & & & & \\
\hline 28 & Mistakes with soil investigations & & & & \\
\hline 29 & Unskilled equipment operators & & & & \\
\hline 30 & Accidents during construction & & & & \\
\hline 31 & Shortage of unskilled labour & & & & \\
\hline 32 & Public holidays & & & & \\
\hline
\end{tabular}

Figure 1 Questionnaire to Rate Level of importance of Delay Factors for Building Construction Projects 